\title{
Expanding Access For Training Of Science Teachers Through ODL: A Case Study Of University Of Lagos, Nigeria
}

A.O. Okunuga, University of Lagos, Nigeria

O. Olaoluniyi, University of Lagos, Nigeria

A. I. Opara, University of Lagos, Nigeria

\begin{abstract}
Rising up to the challenge of shortage of middle manpower in Nigeria, the University of Lagos established the Correspondence and Open Studies Unit (COSU), now Distance Learning Institute DLI). Accounting, Business Administration and Science-Education were the pilot courses at the B.Sc. level. The Special Entry Preparatory Programme (SEPP) was floated to upgrade science teachers with minimal qualifications to the GCE A/L which was the qualification for "direct" admission into the university. The performance of the SEPP group was compared with that of those with GCE A/L when they both came together in the same class. Using the Mann-Whitney non-parametric two-tailed test, it was discovered that the SEPP group performed at the same level as the "direct" group who had GCE A/L upon admission. Stoppage of the SEPP scheme led to a drastic decline in the number of students in the Science programme. Results showed that the SEPP was a viable feeder into the B.Sc. Science-Education programme at the University of Lagos.
\end{abstract}

Keywords: Distance Education; Special Entry Preparatory Program; General Certificate of Education; ScienceEducation

\section{INTRODUCTION}

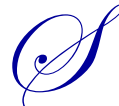

cience is the bedrock of modern civilization, while science and technology are the pillars of modernization. Science gave birth to technology while both of them determined how advanced a civilization is. Science and technology have propelled advanced or developed countries to what they are, while lack of the duo has resulted in some being called developing or underdeveloped countries.

The entity known as Nigeria was subjugated to colonial rule by the British. In the earlier colonial days, the British merchants and missionaries worked to convert the natives to Christianity and gave them basic education so that they could read and write, and thus serve as bookkeepers to the merchants. Thus, the earliest schools were missionary schools; the colonizing British government did not give much concern to higher education and, particularly, the study of sciences.

Thus, at independence, the only university in the country at the time was the University College, Ibadan (UCI), now the University of Ibadan. The university was attached to the apron strings of the University of London. UCI was founded in 1948 and concentrated on the Arts and Classics, while the sciences did not gain any prominence.

At the time of independence in 1960, Nigeria had a gross shortage of the needed manpower to run the services of the nation as these positions were held by British expatriates. Realizing the importance of higher education, the government of the newly-independent Nigeria instituted the Ashby Commission to make recommendations on how to quickly raise the quality and quantity of the needed indigenous manpower for the country (Okunuga, 1985). In its report, the Ashby Commission recommended the establishment of universities in 
major cities in the then existing regions of the country. This resulted in the establishment of Federal Universities in Lagos, Nsukka and Zaria. Because of the metropolitan nature of Lagos, then as the nation's capital and economic centre, the University of Lagos was designed to incorporate both formal and distance teaching in its mode of operation. The distance education mode was to provide a "second chance" for the working masses who, because of work, family, or financial constraints, could not attend to formal education. It was also designed to catch the teeming masses that besiege the city from other parts of the country.

Realizing the importance of science, and faced with the very acute shortage of qualified science teachers in the secondary schools, emphasis was laid on raising qualified science teachers through correspondence/distance teaching mode. Thus, at the establishment of the Correspondence and Open Studies Unit (COSU) in 1973/74 session, science-education was made one of the pivotal pilot programmes of the unit; other programmes established alongside it were Accounting and Business Administration at degree levels; and to bring up teachers who had university degrees but no teaching qualification, a Postgraduate Diploma in Education programme was established (Okunuga, 1985, 2000).

B.Sc. science-education programmes were set up in each branch of the basic sciences - Biology, Chemistry, Physics and Mathematics. While the formal mode of the university ran a three-year programme in these courses, COSU expanded it to a five-year programme. In each case, the criteria for admission was the same - five credit passes at the West African School Certificate examination (WASC) or General Certificate of Education, ordinary level (GCE O/L), plus at least two passes in related science subjects at the GCE Advance Level (GCE A/L). Candidates with the Higher School Certificate (HSC), National Certificate of Education (NCE), or the Higher National Diploma in relevant science courses were admitted into the "direct" three-year full-time or five-year COSU programmes.

The full-time/formal mode had a 'Preliminary' programme for brilliant students who scored high in their West African School Certificate (WASC) or General Certificate of Education (GCE O/L) certificate examinations; they a year of studies before being admitted into the direct course of study. Consequently, COSU, in order to take care of those not in possession of the GCE A/L, created its own Special Entry Preparation Programme (SEPP). As most of the unqualified science teachers in the secondary schools had the Teacher Grade Two certificate (TCII), the SEPP was established to upgrade such TCII teachers and those with only WASC or GCE O/L to the level of GCE $\mathrm{A} / \mathrm{L}$. Thus, those with WASC/GCE O/L, having five credits, including relevant science courses, were admitted into a one-year SEPP and spent a minimum of six years for their B.Sc. education-science courses at COSU. Holders of TCII with at least credit/merit in five subjects, including English, Mathematics, and General Science, were admitted into a two-year SEPP course of study. Further, to encourage interest in the sciences, those who had City and Guilds $(C \& G)$ or variant qualification in Home Economics, Technical Drawing, print and Textile, Woodwork, etc., were given admission into the two-year SEPP. Also admitted into this category were Head teachers who possessed the Professional Studies in Education (PSE) with Science and Mathematics from the University of Lagos or any university of the same status in Nigeria.

\section{RATIONALE FOR THE STUDY}

The SEPP course of study was designed to train the holders of WASC/GCE O/L, TCII, Associate Certificate in Education (ACE), PSE, and others not qualified for "direct" admission, up to the Advance Level of GCE, HSC or NCE, which were the required qualifications for "direct" admission into the universities in Nigeria. It was presumed that upon passing the SEPP courses, the student would be at par with those admitted "directly". This study looked into the SEPP course of study as an effective feeder into the Science-Education programme of the old COSU/COSIT. Though the SEPP was abolished in the 1989/90 session, a look at its effectiveness is imperative. This study could be an eye-opener to those who want to set up such a feeder programme.

\section{REVIEW OF RELATED LITERATURE}

Determining the factors governing the academic performance of students is a challenging task as this is a product of various factors, such as psychological, socio-economic, and environmental factors (Kooi and Ping, 2007). The variables in these factors that may affect academic performance include gender, age, prior academic 
achievements, prior area of study, work, reading comprehension, scientific reasoning, perceptual ability, and years away from academics (study) (Kim and Lee, 2007). The relationships are outlined in Figure 1.

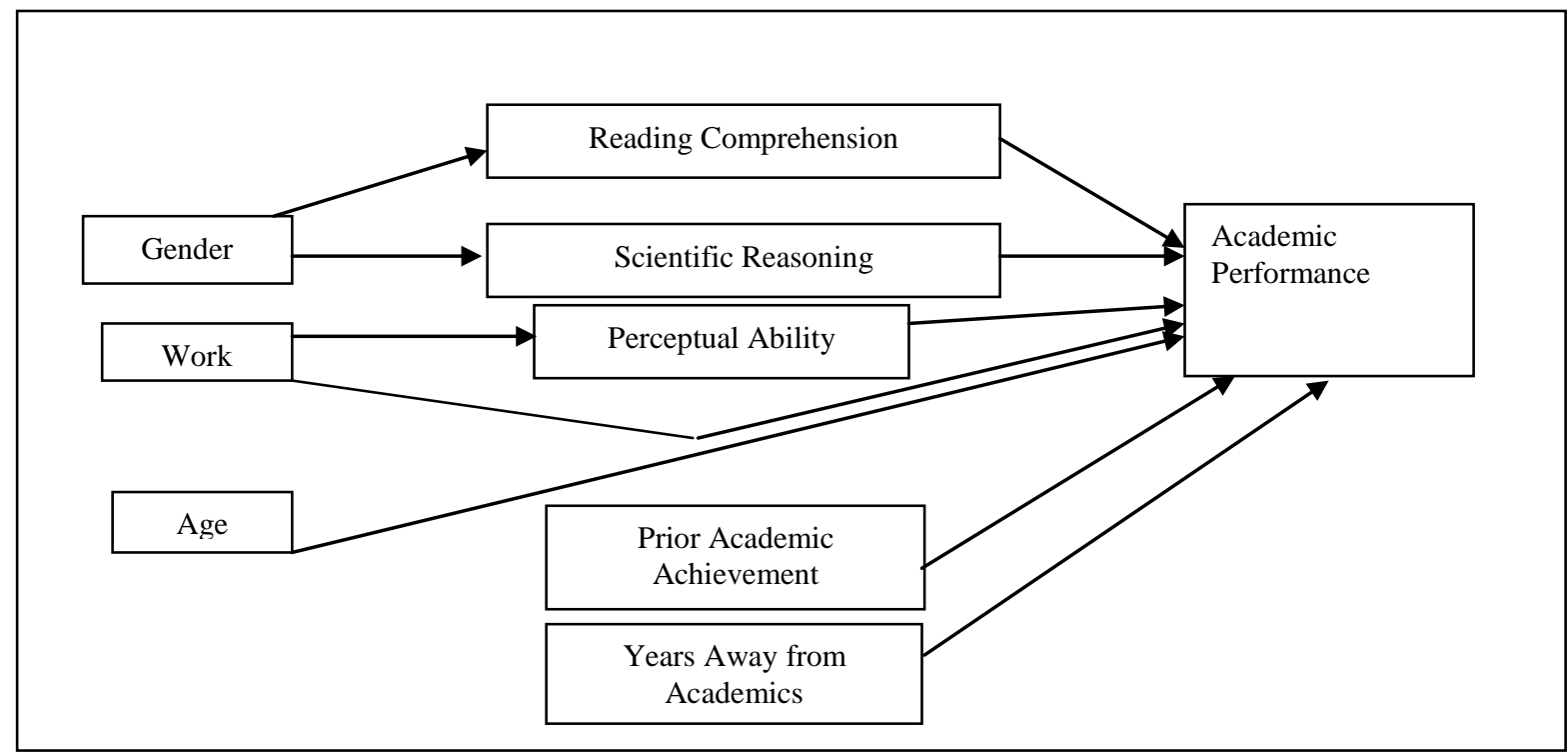

Figure 1: Hypothesized Model of Relationships Among Variables

that May Affect Academic Performance (Modified from Kim and Lee, 2007)

Kim and Lee (2007) stated that females do better than males in reading and comprehension, while males perform better in perceptual ability and scientific reasoning. Some other researchers found that females out-perform males when course work is the mode of assessment (Alfam and Othman, 2005; Woodfield et al, 2005; Naylor and Smith, 2004; Smith, 2004; Lee, 2003; Lumsden and Scott, 1987).

Hoffman and van den Berg (2000) were of the opinion that work interferes with academic performance in that students who work during term-time perform less well than those who do not. However, they stated that students who have relevant work experience perform better than those who do not (Gracia and Jenkins, 2003). This was also supported by Keast (1998).

Researchers are split on the effect of age on academic performances. Some have indeed found that older students did less well in reasoning in the sciences and tended to score lower than younger ones (Aldous et al, 1999; Huff and Fang, 1999; Kay, Pearson and Rolfe, 2002). However, in Rolfe et al (1995) and James and Chilvers' (2001) studies, they suggested that the older and mature medical students achieved better overall when compared to their younger counterparts. This opinion was supported by Jensen and Bruinsola (2005), Wojciechonoski and Palma (2005), Shamahan (2004), and Richardson and Woodley (2003). Blackman and Darwamam (2004) stated that examination scores (performance) were directly, but negatively, influenced by the student's age.

Kooi and Ping (2001) opined that the combined factors of age and academic background have very little significant effect on students' performance. However, they stated that these factors independently significantly affect academic performance as measured by grade point average (GPA). Merisortis and Phipps (1999) identified grades and test scores as one of the means to determine the effectiveness of distance education. Josey (1997) regarded GPA as a numerical of academic performance.

Chensarkar and Michaeloudis (2001) opined that age does not affect students' academic performance, but that prior academic qualification does in the context of quantitative subjects. Alslete and Bentell (2004) stated that prior academic qualifications are not significant factors in students' performance, while Kooi and Ping (2007) averred that prior formal education at a more advanced level helps students thrive through their tertiary studies less strenuously. 
Olatoye (2007) stressed the importance of mathematics in the understanding of all branches of science. Many topics in science subjects cannot be understood without a sound knowledge of mathematics (Odousoro, 2000). Setidisho (1996) rated that mathematics is a fundamental science which is necessary for the understanding of most other fields of science. Kalejaiye (1985) and Odeyemi (1995) affirmed that mathematics is the language of science and central to intellectual discipline. Olatoye further emphasized the additional importance of further mathematics in the enhancement of better performance in the sciences.

Many institutions keep a pool of data on their students which includes their entry academic backgrounds. These are used, among other things, in identifying the attributes that contribute the most significantly to students' academic performance. Based on these factors, the institutions devise ways to improve the intervention strategies and support services for students who perform poorly in earlier parts of their studies (Affendey et al, 2010). Studies on factors affecting students' academic performance can also guide curriculum planning committees in effecting changes to the curriculum and evaluating the effects of those changes. Also, an instructor can use it to improve his/her teaching and learning approach to further enhance interventions and support services for weak students (Affendey et al, 2010). Furthermore, an institution can use it to modify its admission policies so as to place students in appropriate class levels based on their previous academic performances.

\section{MODE OF OPERATION OF SEPP SCIENCE-EDUCATION}

Students admitted into the SEPP Science-Education course of study took two science subjects - one as the major and the other as the minor subject. A student with Biology as a major had Chemistry as a minor subject. Chemistry majors had the options of Physics, Biology, or Mathematics as minors. The minors for a Physics major are Chemistry or Mathematics. Mathematics majors had Chemistry, Physics, or Mathematics (i.e., Pure and Applied) as minors. This was so that the science teacher could teach at least two science subjects in the secondary schools. The SEPP courses are listed in Table 1.

Thus, a Biology major student took the following courses: BIY 001, 002, 003, and CHM 001, 002, 003, and 004. For Chemistry major, the subjects are CHM 001, 002, 003, and 004, and those with Biology as a minor took BIY 001, 002, and 003. Chemistry major/Physics minor students took Chemistry courses as well as PHS 001007. Chemistry/Mathematics students took Chemistry courses as well as MAT 021-023. With Mathematics major and minor, students took MAT 021-026. Mathematics/Physics students took MAT 021-026 and PHS 001-007. Mathematics/Chemistry SEPP students took MAT 021-026 and CHM 001-004.

Table 1: Courses of the SEPP Science-Education Course of Study

\begin{tabular}{|c|c|c|c|}
\hline Course of Study & Course Code & Course Title & Units \\
\hline SEPP & BIY 001 & Introductory Cell Biology & $2 \mathrm{C}$ \\
\hline \multirow[t]{2}{*}{ Biology } & BIY 002 & Introductory Organismal Biology & $2 \mathrm{C}$ \\
\hline & BIY 003 & Organisms and the Environment & $2 \mathrm{C}$ \\
\hline \multirow[t]{4}{*}{ Chemistry } & CHM 001 & Inorganic Chemistry & $2 \mathrm{C}$ \\
\hline & CHM 002 & Organic Chemistry & $2 \mathrm{C}$ \\
\hline & CHM 003 & Physical Chemistry & $2 \mathrm{C}$ \\
\hline & CHM 004 & Chemistry Practicals & $2 \mathrm{C}$ \\
\hline \multirow[t]{7}{*}{ Physics } & PHS 001 & General Physics & $1 \mathrm{C}$ \\
\hline & PHS 002 & Heat & $1 \mathrm{C}$ \\
\hline & PHS 003 & Electricity and Magnetism & $1 \mathrm{C}$ \\
\hline & PHS 004 & Optics & $1 \mathrm{C}$ \\
\hline & PHS 005 & Oscillation, Waves and Sound & $1 \mathrm{C}$ \\
\hline & PHS 006 & Modern Physics & $1 \mathrm{C}$ \\
\hline & PHS 007 & Preliminary Laboratory Physics & $1 \mathrm{C}$ \\
\hline \multirow[t]{6}{*}{ Mathematics } & MAT 021 & Pure Mathematics I & $2 \mathrm{C}$ \\
\hline & MAT 022 & Pure Mathematics II & $2 \mathrm{C}$ \\
\hline & MAT 023 & Pure Mathematics III & $2 \mathrm{C}$ \\
\hline & MAT 024 & Applied Mathematics I & $2 \mathrm{C}$ \\
\hline & MAT 025 & Applied Mathematics III & $2 \mathrm{C}$ \\
\hline & MAT 026 & Applied Mathematics III & $2 \mathrm{C}$ \\
\hline
\end{tabular}

$\mathrm{C}=$ Compulsory; $\mathrm{R}=$ University requirement 
To be considered successful at the SEPP level, a student must sit for the major and minor subjects and pass each with an average of $40 \%$. A student who passed one but not the other sat for a Resit examination in all the failed subjects. Successful students then moved on to the next level; i.e., Year 2/Part 1A where they combined with newly admitted students with GCE A/L, NCE, or HND. The courses taken in Year 2/Part IA are listed in Table 2 and include both science and education subjects. The aims of this study are to compare the performance of the SEPP and Direct (DR) groups and to see if the SEPP had prepared its students to the level of the DR group.

Table 2: Courses Taken in the Year 2/Part 1A

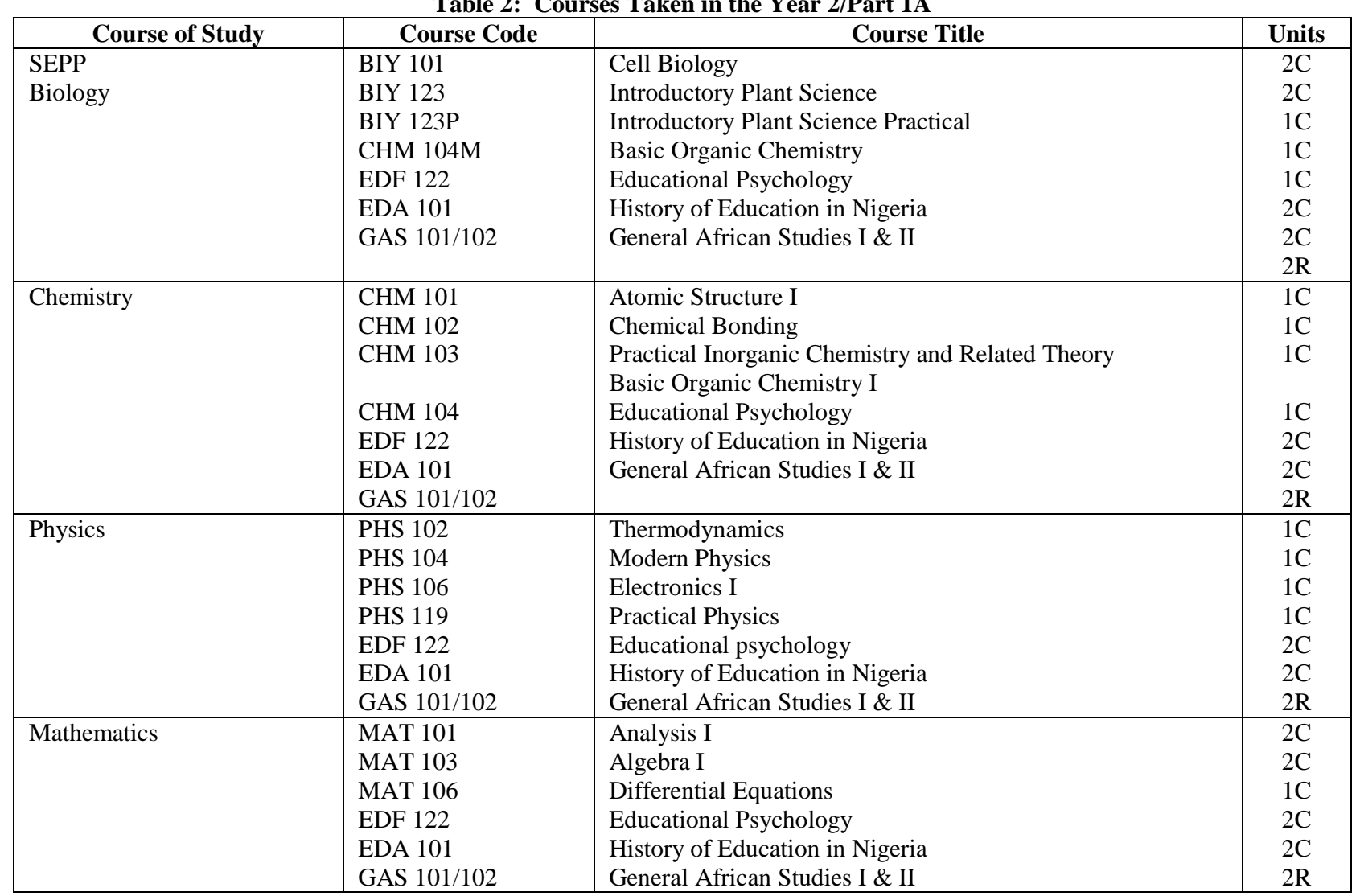

$\mathrm{C}=$ Compulsory; $\mathrm{R}=$ University requirement

\section{METHOD OF ANALYSIS}

Records of performance at examinations by the SEPP and DR groups in Year 2/Part 1A were obtained from the Record Office of the Distance Learning Institute, University of Lagos. The two groups were identified by their matriculation numbers. The grades were thus weighted:

$90-100-6$

$70-89-5$

$60-69-4$

$50-59-3$

$40-49-2$

$35-39-1$

$0-34-0$

The Mann-Whitney U test - a non-parametric test method - was used to comparatively analyze the performance of the two groups. First, the two samples were combined and the combined samples were ranked, keeping track of the sample to which each observation belongs (Okafor, 2004). 
Let $S_{m}$ be the sum of the ranks assigned to the SEPP sample, $S_{n}$ assigned to the Direct entry (DR) group, the SEPP sample being of size, $m$, while the DR sample is of size $n$; then:

$\mathrm{T}_{\mathrm{m}}=\mathrm{S}_{\mathrm{m}}-\frac{\mathrm{m}(\mathrm{m}+1)}{2}$ and

$T_{n}=S_{n}-\frac{n(n+1)}{2}$

We can use $T_{m}$ or $T_{n}$ to test the hypothesis.

$\mathbf{H}_{\mathbf{0}}: \quad \mathrm{M}_{\mathrm{m}}=\mathrm{M}_{\mathrm{n}}$ (i.e., SEPP students perform equally as well as DR students)

$\mathbf{H}_{1}$ : $\quad \mathrm{M}_{\mathrm{m}}<\mathrm{M}_{\mathrm{n}}$ (i.e., SEPP students' performance is lower than that of DR Students)

where $\mathrm{M}_{\mathrm{m}}$ is the median of the sample of size $m$ and $\mathrm{M}_{\mathrm{n}}$ is the median of the sample of size $n$;

then, $\left.\mathrm{T}_{\mathrm{m}} \sim \mathrm{N} \underline{\mathrm{mn}}, \frac{\mathrm{mn}(\mathrm{m}+1)}{2 \quad 12}\right)$

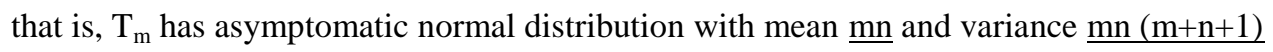

2

12

The data were subjected to the Statistical Package for Social Sciences (SPSS 15) at $p>0.05$. If the calculated p-value of the test is less than 0.05 , we reject $\mathrm{H}_{\mathrm{o}}$. The rejection of $\mathrm{H}_{\mathrm{o}}$ means that one group performed better than the other and the sum of the ranks will indicate the better group.

\section{RESULTS}

The outcomes of the comparison of performance of the SEPP and DR groups in Science-Education courses are listed in Tables 3-6. Where the calculated p-value (Asymptomatic significance) is less than 0.05 (i.e., <0.05), then there is a significant difference in the performances; the group having a higher Mean Rank had the better performance. A p-value greater than $0.05(>0.05)$ shows that there is no significant difference in the performances; this is represented by the equivalency $(\equiv)$ sign.

Table 3 shows that the DR group performed better than the SEPP group in BIY 101 and CHM 104T, while the SEPP group was better in EDF 122. There was no significant difference in the performances of the two groups in three courses; namely, BIY 123P, BIY 123, and EDA 101.

Table 4 shows the DR performing better in two courses - CHM 101 and CHM 103 - while there were no differences in their performances in five courses; namely, CHM 102, 104 M, EDA 101, EDF 122, and GAS $101 / 102$.

Comparison of performance of the two groups in Physics-Education is listed in Table 5. The SEPP group out-performed the DR group in PHS 102, while the DR performed better in GAS 101/102. The two groups recorded equal performances in four courses - vis PHS 104, 106, EDA 101, and EDF 122.

Performances of the two groups in Mathematics-Education courses are listed in Table 6, with the DR performing better in MAT 103, while SEPP performed better in GAS 101/102. There were no significant differences in performances of the two groups in four courses; namely, MAT 101, 106, EDA 101, and EDF 122. 
Table 3: Summary of Mann-Whitney's 2-tailed Test on Performances of SEPP and DR Groups in Biology-Education Courses

\begin{tabular}{|c|c|c|c|c|c|c|}
\hline Course & Group & $\mathbf{N}$ & Mean Rank & Sum of Ranks & $\begin{array}{c}\text { Asymptomatic Significance } \\
\text { (2-tailed) }\end{array}$ & Performance Rating \\
\hline \multirow[t]{2}{*}{ BIY 101} & SEPP & 153 & 108.90 & 16661.00 & \multirow[t]{2}{*}{0.000} & \multirow[t]{2}{*}{ DR > SEPP } \\
\hline & DR & 118 & 171.14 & 20195.00 & & \\
\hline \multirow[t]{2}{*}{ BIY 123P } & SEPP & 126 & 119.04 & 14999.00 & \multirow[t]{2}{*}{0.481} & \multirow[t]{2}{*}{$\mathrm{SEPP} \equiv \mathrm{DR}$} \\
\hline & DR & 117 & 125.19 & 14647.00 & & \\
\hline \multirow[t]{2}{*}{ BIY 123} & SEPP & 131 & 145.61 & 19074.50 & \multirow[t]{2}{*}{0.255} & \multirow[t]{2}{*}{$\mathrm{SEPP} \equiv \mathrm{DR}$} \\
\hline & DR & 172 & 156.87 & 26981.50 & & \\
\hline \multirow[t]{2}{*}{ CHM 104T } & SEPP & 116 & 94.84 & 11001.50 & \multirow[t]{2}{*}{0.000} & \multirow[t]{2}{*}{ DR $>$ SEPP } \\
\hline & DR & 107 & 130.60 & 13974.50 & & \\
\hline \multirow[t]{2}{*}{ EDA 101} & SEPP & 167 & 129.81 & 21678.00 & \multirow[t]{2}{*}{0.425} & \multirow[t]{2}{*}{$\mathrm{SEPP} \equiv \mathrm{DR}$} \\
\hline & DR & 97 & 137.13 & 13302.00 & & \\
\hline \multirow[t]{2}{*}{ EDF 122} & SEPP & 44 & 97.34 & 4283.00 & \multirow[t]{2}{*}{0.006} & \multirow[t]{2}{*}{ SEPP > DR } \\
\hline & DR & 119 & 76.33 & 9083.00 & & \\
\hline
\end{tabular}

Key: $\quad$ SEPP $=$ Special Entry Preparatory Programme group.

$\mathrm{DR}=$ Direct entry group.

$\equiv$ : equal performance, no significant difference in performance

>: higher performance

Table 4: Summary of Mann-Whitney's 2-tailed Test on Performances of SEPP and DR Groups in Chemistry-Education Courses

\begin{tabular}{|c|c|c|c|c|c|c|}
\hline Course & Group & $\mathbf{N}$ & Mean Rank & Sum of Ranks & $\begin{array}{c}\text { Asymptomatic Significance } \\
\text { (2-tailed) }\end{array}$ & Performance Rating \\
\hline \multirow[t]{2}{*}{ CHM 101} & SEPP & 59 & 61.06 & 3602.50 & \multirow[t]{2}{*}{0.000} & \multirow[t]{2}{*}{$\mathrm{DR}>\mathrm{SEPP}$} \\
\hline & DR & 94 & 87.01 & 8178.50 & & \\
\hline \multirow[t]{2}{*}{ CHM 102} & SEPP & 55 & 79.08 & 4349.50 & \multirow[t]{2}{*}{0.054} & \multirow[t]{2}{*}{$\mathrm{SEPP} \equiv \mathrm{DR}$} \\
\hline & DR & 86 & 65.83 & 5661.50 & & \\
\hline \multirow[t]{2}{*}{ CHM 103} & SEPP & 66 & 63.64 & 3818.50 & \multirow[t]{2}{*}{0.020} & \multirow[t]{2}{*}{ SEPP > DR } \\
\hline & DR & 85 & 79.61 & 6766.50 & & \\
\hline \multirow[t]{2}{*}{ CHM $104 \mathrm{M}$} & SEPP & 54 & 62.72 & 3387.00 & \multirow[t]{2}{*}{0.118} & \multirow[t]{2}{*}{$\mathrm{DR} \equiv \mathrm{SEPP}$} \\
\hline & DR & 83 & 73.08 & 6066.00 & & \\
\hline \multirow[t]{2}{*}{ EDA 101} & SEPP & 62 & 68.24 & 4231.00 & \multirow[t]{2}{*}{0.265} & \multirow[t]{2}{*}{$\mathrm{SEPP} \equiv \mathrm{DR}$} \\
\hline & DR & 82 & 75.72 & 6209.00 & & \\
\hline \multirow[t]{2}{*}{ EDF 122} & SEPP & 57 & 66.84 & 3810.00 & \multirow[t]{2}{*}{0.272} & \multirow[t]{2}{*}{$\mathrm{SEPP} \equiv \mathrm{DR}$} \\
\hline & DR & 84 & 73.82 & 6201.00 & & \\
\hline \multirow[t]{2}{*}{ EDF 122} & SEPP & 49 & 43.39 & 2126.00 & \multirow[t]{2}{*}{0.190} & \multirow[t]{2}{*}{$\mathrm{SEPP} \equiv \mathrm{DR}$} \\
\hline & DR & 43 & 50.05 & 2152.00 & & \\
\hline
\end{tabular}

Key: $\quad$ SEPP = Special Entry Preparatory Programme group.

$\mathrm{DR}=$ Direct entry group.

$\equiv$ : equal performance, no significant difference in performance

$>$ : higher performance

Table 5: Summary of Mann-Whitney's 2-tailed Test on Performances of SEPP and DR Groups in Physics-Education Courses

\begin{tabular}{|c|c|c|c|c|c|c|}
\hline Course & Group & $\mathbf{N}$ & Mean Rank & Sum of Ranks & $\begin{array}{c}\text { Asymptomatic Significance } \\
\text { (2-tailed) }\end{array}$ & Performance Rating \\
\hline \multirow[t]{2}{*}{ PHS 102} & SEPP & 59 & 69.08 & 4075.50 & \multirow[t]{2}{*}{0.029} & \multirow[t]{2}{*}{ DR $>$ SEPP } \\
\hline & DR & 64 & 55.48 & 3550.50 & & \\
\hline \multirow[t]{2}{*}{ PHS 104} & SEPP & 55 & 57.90 & 3184.50 & \multirow[t]{2}{*}{0.521} & \multirow[t]{2}{*}{$\mathrm{SEPP} \equiv \mathrm{DR}$} \\
\hline & DR & 64 & 61.80 & 3955.50 & & \\
\hline \multirow[t]{2}{*}{ PHS 106} & SEPP & 50 & 59.85 & 2992.50 & \multirow[t]{2}{*}{0.595} & \multirow[t]{2}{*}{ SEPP > DR } \\
\hline & DR & 65 & 56.58 & 3677.50 & & \\
\hline \multirow[t]{2}{*}{ EDA 101} & SEPP & 49 & 54.63 & 2677.00 & \multirow[t]{2}{*}{0.468} & \multirow[t]{2}{*}{$\mathrm{DR} \equiv \mathrm{SEPP}$} \\
\hline & DR & 64 & 58.81 & 3764.00 & & \\
\hline \multirow[t]{2}{*}{ EDF 122} & SEPP & 49 & 53.22 & 2554.50 & \multirow[t]{2}{*}{0.318} & \multirow[t]{2}{*}{$\mathrm{SEPP} \equiv \mathrm{DR}$} \\
\hline & DR & 64 & 58.96 & 3773.50 & & \\
\hline
\end{tabular}




\begin{tabular}{|l|l|l|l|l|l|l|}
\hline GAS & SEPP & 19 & 11.53 & 219.00 & 0.00 & SEPP $\equiv$ DR \\
\cline { 2 - 5 } & DR & 19 & 27.47 & 522.00 & & \\
\hline
\end{tabular}

Key: $\quad$ SEPP = Special Entry Preparatory Programme group.

$\mathrm{DR}=$ Direct entry group.

$\equiv$ : equal performance, no significant difference in performance

$>$ : higher performance

Table 6: Summary of Mann-Whitney's 2-tailed Test on Performances of SEPP and DR Groups in Mathematics-Education Courses

\begin{tabular}{|c|c|c|c|c|c|c|}
\hline Course & Group & $\mathbf{N}$ & Mean Rank & Sum of Ranks & $\begin{array}{c}\text { Asymptomatic Significance } \\
\text { (2-tailed) }\end{array}$ & Performance Rating \\
\hline \multirow[t]{2}{*}{ MAT 101} & SEPP & 94 & 135.14 & 12703.50 & \multirow[t]{2}{*}{0.57} & \multirow[t]{2}{*}{ DR > SEPP } \\
\hline & DR & 202 & 154.72 & 31252.50 & & \\
\hline \multirow[t]{2}{*}{ MAT 103} & SEPP & 87 & 119.02 & 10354.50 & \multirow[t]{2}{*}{0.003} & \multirow[t]{2}{*}{$\mathrm{SEPP} \equiv \mathrm{DR}$} \\
\hline & DR & 191 & 148.83 & 28426.50 & & \\
\hline \multirow[t]{2}{*}{ MAT 106} & SEPP & 72 & 148.72 & 10708.00 & \multirow[t]{2}{*}{0.72} & \multirow[t]{2}{*}{ SEPP > DR } \\
\hline & DR & 197 & 129.98 & 25607.00 & & \\
\hline \multirow[t]{2}{*}{ EDA 101} & SEPP & 84 & 143.09 & 12306.08 & \multirow[t]{2}{*}{0.104} & \multirow[t]{2}{*}{$\mathrm{DR} \equiv \mathrm{SEPP}$} \\
\hline & DR & 224 & 160.26 & 35899.00 & & \\
\hline \multirow[t]{2}{*}{ EDF 122} & SEPP & 97 & 153.43 & 14882.50 & \multirow[t]{2}{*}{0.765} & \multirow[t]{2}{*}{$\mathrm{SEPP} \equiv \mathrm{DR}$} \\
\hline & DR & 213 & 156.44 & 33322.50 & & \\
\hline \multirow{2}{*}{$\begin{array}{l}\text { GAS } \\
101 / 102\end{array}$} & SEPP & 19 & 49.16 & 934.00 & \multirow[t]{2}{*}{0.00} & \multirow[t]{2}{*}{$\mathrm{SEPP} \equiv \mathrm{DR}$} \\
\hline & DR & 45 & 25.47 & 1146.00 & & \\
\hline
\end{tabular}

Key: $\quad$ SEPP $=$ Special Entry Preparatory Programme group.

$\mathrm{DR}=$ Direct entry group.

$\equiv$ : equal performance, no significant difference in performance

$>\quad$ : higher performance

\section{Effect of Stoppage of SEPP}

In the 1990/91 session, the SEPP was discontinued because of the change in course system in the formal mode of the university. Instead of the two subject combination of the SEPP (i.e., Biology/Chemistry, Chemistry/Physics, Chemistry/Mathematics, Physics/Mathematics, and Pure/Applied Mathematics), new intakes were required to take various courses in all the science subjects, plus Computer Science and Education courses. The resultant effect was a drastic decline in the number of admitted candidates who took up admission. Besides the change in course curricula, the tenure was also increased to seven years so that those who could have read the SEPP in one year had to do it in two years before advancing to the "Direct" class. Hence, as shown in the Table 7, the number of Science students decreased drastically over the years until the institute - in 2000/01 to 2003/04 sessions did not admit new students. In the 2005/06 session, admission was re-opened, but with stricter requirements that made candidates opt for non-science courses. All of these are clear indications of the importance of the SEPP as a viable feeder into the Science-Education programme.

Table 7: Enrollment in the SEPP Scheme 1984/85 - 2006/07

\begin{tabular}{|c|c|c|c|}
\hline Session & SEPP & Direct & Total Intake \\
\hline $84 / 85$ & 194 & 175 & 369 \\
\hline $85 / 86$ & 246 & 563 & 809 \\
\hline $86 / 87$ & 304 & 668 & 972 \\
\hline $87 / 88$ & 311 & 265 & 567 \\
\hline $88 / 89$ & 205 & 145 & 350 \\
\hline $89 / 90$ & 231 & 319 & 550 \\
\hline $90 / 91$ & - & $(118), 146$ & 264 \\
\hline $91 / 92$ & - & $(94), 127$ & 221 \\
\hline $92 / 93$ & - & $(82), 171$ & 253 \\
\hline $94 / 95$ & - & $(13), 73$ & 86 \\
\hline $95 / 96$ & - & $(18), 31$ & 49 \\
\hline $96 / 97$ & - & $(10), 23$ & 33 \\
\hline $97 / 98$ & - & $(8), 8$ & 16 \\
\hline
\end{tabular}




\begin{tabular}{|c|c|c|c|}
\hline & - & $(9), 12$ & 21 \\
\hline $98 / 99$ & - & - & 20 \\
\hline $00 / 01$ & - & - & - \\
\hline $01 / 02$ & - & - & - \\
\hline $02 / 03$ & - & - & - \\
\hline $03 / 04$ & - & $(0), 29$ & 29 \\
\hline $05 / 06$ & - & $(27), 78$ & 115 \\
\hline $06 / 07$ & - & & \\
\hline
\end{tabular}

Note: There were no academic sessions in 93/94 and 04/05; no admission between 01/02 and 03/04 sessions. From 90/91 when SEPP was abolished, those who could have gone into SEPP were admitted into years 1 and 2 of a seven-year programme their numbers are in parenthesis.

\section{CONCLUSION}

The Special Entry Preparatory Programme (SEPP) was set up to admit candidates who did not have the academic qualifications for direct admission into the university. The needed qualification was the Advance Level of the General Certificate in Education (GCE A/L). Hence, candidates with the GCE Ordinary Level, Teachers' Grade Two Certificate (TCII), and others with such qualifications, were admitted into SEPP with the hope of being brought up to the level of GCE A/L, HSC, or NCE. The SEPP was only for the Science-Education B.Sc. studies in Biology, Chemistry, Physics, and Mathematics.

Findings from the performance results of the SEPP and DR groups in Part IA/Year 2 of the B.Sc. programme showed no significant difference in the performance of the two groups in the majority of the courses. In a few courses, the DR performed better than the SEPP group, while the SEPP also performed better in as many courses. Student population drastically decreased when the SEPP was scrapped, leading to stoppage of admission for a few years. From the findings, it can be adduced that the SEPP was a viable feeder programme into the B.Sc. Science-Education programme of the Correspondence and Open Studies Institute (COSIT, now Distance Learning Institute, DLI) of the University of Lagos. This study would be of interest to other countries/institutions facing similar problems of shortage of qualified science teachers.

\section{AUTHOR INFORMATION}

A.O. Okunuga, University of Lagos, Head, Science-Education Programme, Nigeria. E-mail: ceedeeokuns@yahoo.com (Corresponding author)

O. Olaoluniyi, University of Lagos, Distance Learning Institute Nigeria. E-mail: oolaoluniyi@unilag.edu.ng

A. I. Opara, University of Lagos, Distance Learning Institute, Nigeria. E-mail: oparaathanasius2008@yahoo.com

\section{REFERENCES}

1. Affendy, L.S. , Paris, I.H.M., Mustapha, N., Nasir Sulaiman, Md. And Muda, Z. (2010). Ranking of influence Factors in predicting students' performance. Information Technology Journal, 9:832-837.

2. Aldous, C., Leeder, S., Price, J., Sefton, A. and Tuebner, J. (1997). A selection of tests for Australian graduate-entry medical schools. Medical Journal of Australia. 166:247-250.

3. Alfan, E. and M.N. Othman. (2005). Undergraduate students' achievement: the case of University of Malay. Quality Assurance in Education, 13(4): 329-343.

4. Blackman, Ian and Darmawan, I. Gusti Ngurah Darmawan (2004). Graduate-Entry Medical Student variables that Predict Academic and Clinical Achievement: International Education.

5. Chansarkar, B.A., and A. Michaeloudis (2004). Student profiles and factors affecting performance. International Journal of Mathematics, Education Science and Technology, Volume 32(1) 97-104.

6. Gracia, L and E. Jenkins (2003). A quantitative exploration of students' performance on an undergraduate accounting programme of study. Accounting Education, 12(1): 15-32.

7. Hoffman, A and Van Den Berg (2000). Determinants of study progress: the impact of student, curricular and contextual factors on study progress in university education. Higher Education in Europe, 25(1): 93110.

(C) 2013 The Clute Institute http://www.cluteinstitute.com/ 
8. Huff, K. and Fang, D. (1999). When are students most at risk of encountering academic difficulty? A study of the 1992 matriculants to US Medical Schools. Academic Medicine 74, 454-460.

9. James, D. and C. Chilvers (2004). Academic and non-academic predictors of success on the Nottingham undergraduate medical course. 1970-1995. Medical Education 35:1056-1064.

10. Jansen, E. and Bruinsma (2005). Explaining achievement in higher education. Educational Research and Education, 11(3): 235-252.

11. Josey, Bass (1977). Selective admissions in higher education. Carnegie Foundation for the Advancement of Teaching.

12. Kalejaye, A.O. (1985). Problem of teaching mathematics in our schools. Nigerian Observer. $18^{\text {th }}$ March, 1985, p.7.

13. Kay, L., S. Pearson and I. Rolfe (2002). The influence of admission variables on first year medical school performance. A study from Newcastle University, Australia. Medical Education. 36:154-159.

14. Kim, Minkang and Jae II Lee. 2007. Variables Predicting Student's First Semester Achievement in a Graduate-Entry Dental School in Korea. Journal of Dental Education. 74(4): 550-556.

15. Kooi, Lew Teik and Teoh Ai Ping. 2007. Factors Influencing Student's Performance in WAWASAN Open University: Does previous education level, age group and course load matter? Internet Article.

16. Lee, A.C.K. (2003). Undergraduate students' gender differences in IT skills and attitudes. Journal of Computer-Assisted Learning, 19(4): 488-500.

17. Lumsden, K.G. and A. Scott. (1987). The economics students re-examined: male-female differences in comprehension. Journal of Economic Education, 18(4): 365-374.

18. Merisortis, J. and R. Phipps (1999). What's the difference? Outcomes of distance Vs traditional classroom-based learning. Change 31(2): 12-17.

19. Naylor, R. and J. Smith (2004). Degree of achievement of economics students in the UK universities: absolute and relative achievements in prior qualifications. Scottish Journal of Political Economy, 51(2): 250-265.

20. Odeyemi, J.O. (1995). On how to avoid hazard in the teaching of set concept. Abacus Journal of Mathematics Association of Nigeria, 2(1): 33-34.

21. Odousoro, U.I. (2000). The relative effects of computer and test assisted programmed instruction on students' learning outcomes in mathematics. An unpublished PhD Thesis. University of Ibadan, Ibadan, Nigeria.

22. Olatoye, Ademola R. (2007). Effect of Further Mathematics on Students' Achievement in Mathematics, Biology, Chemistry and Physics. International Journal of Environmental Science-Education, 2(2): 48-53. IJESE from Australia.

23. Okunuga, Gboyega O. (1985). Face-to-face instruction in distance learning: Problems and Issues. Nigeria Education Forum, 8(2): 169-180.

24. Okunuga, A.O. (2000). Operation of a Distance Education System at COSIT, University of Lagos, Nigeria. Ghana Journal of Literacy and Adult Education, 2: 269-275.

25. Richardson, J. and A. Woodley (2003). Another look at the role of age, gender and subject as predictors of academic attainment in higher education. Studies in Higher Education, 28(4): 475-493.

26. Rolfe, I.S., D. Powis Pearson and A. Smith (1995). Time for a review of admission to Medical School? Lancet, 346: 1329-1333.

27. Setidisho, N.O.H. (1996). Aims of teaching mathematics. West African Journal of Education, 4(3): 251260.

28. Shanahan, M.M. (2004). Does age at entry have an impact on academic achievement among MexicanAmerican language - minority students? Sociology of Education, 71(1): 68-93.

29. Smith, F. (2004). "It is not all about grades": accounting for gendered degree results in geography at Brunel University. Journal of Geography in Higher Education, 28(2): 167-168.

30. Wojciechowski, A. and L.B. Palmer (2005). Individual Students' Characteristics: can any be predictors of success in on-line classes? On-line Journal of Distance Learning Education, 8(2).

31. Woodfield, R., S. Earl-Novell and L. Solomon (2005). Gender and mode of assessment at university: should we assume female students are better suited to course work and males to unseen examinations? Assessment and Evaluation in Higher Education, 30(1): 35-50. 